\title{
Effect of consolidation treatments on mechanical behaviour of sandstone
}

\author{
Marco Ludovico-Marques ${ }^{\mathrm{a}, *}$, Carlos Chastre ${ }^{\mathrm{b}}$ \\ "CICC, Barreiro School of Technalogy, Palytechric Institute of Setúbal, Portugal \\ "UNC, Dept. of Civil Engineering, FCT, Universidade Nova de lisboa, Partugal
}

\section{H I G H L I G H T S}

- Consolidation on sandstones with ethyl silicates increased mechanical parameters.

- Strength values of monotonic and cyclic compression are similar after treatments.

- A model describes compressive mechanical behaviour of consolidated building stones.

\section{A RTICLE I N F O}

\section{Artide histary:}

Received 5 February 2014

Received in revised form 2 August 2014

Accepted 5 August 2014

\section{Keywords:}

Monuments

Sandstone

Ehyl silicates

Compression

Consolidation effect

\begin{abstract}
A B S T R A C T
Experimental research was carried out about into ethyl silicate applications on sandstone samples, Consolidation was assessed by drilling strength, impregnation depth and also monotonic and cyclic uniaxial compressive tests in order to evaluate the compressive mechanical behaviour of treated sandstone. The stress-strain compression diagrams showed a significant increase in the values of mechanical parameters after consolidation treatments. The difference in compressive strength values between monotonic and cyclic compression dis appears after the consolidation treatments. An equation of consolidation effect was obtained from an analytical model by means of compressive behaviour assessed by stress-strain diagrams.

These sandstone samples have values of porosity similar to the more weathered variety of sandstone found in facades of monuments in the village of Atouguia da Baleia, in the western region of Portugal. The most important degradation pattern found on sandstone building stones is alveolization caused by salt crystallization since the Middle Ages.
\end{abstract}

Q 2014 Elsevier Itd. All rights reserved. 